\title{
Peningkatan Kinerja Karyawan Melalui Motivasi Kerja dan Kompensasi Pada PT Matahari Department Store Cabang Cibubur
}

\author{
Eigis Yani Pramularso ${ }^{* *}$ \\ ${ }^{1}$ Program Studi Manajemen Fakultas Ekonomi dan Bisnis \\ Universitas Bina Sarana Informatika \\ *Email: eigis.eyp@bsi.ac.id
}

Naskah diterima 14 Januari 2021, Revisi 15 Maret 2021, Terbit 29 April 2021

\begin{abstract}
DOI: doi.org/10.21107/pamator.v14i1.9453

Work motivation and compensation are factors that are expected to maintain employee performance. With good work motivation and compensation, it is hoped that employees will always be sincere, have morale, and are happy to do their job. The purpose of this study was to determine the effect of work motivation factors and compensation factors on employee performance at PT Matahari Department Store Cibubur Branch. In this study, the population as well as the sample were all employees of the cashier, totaling 32 with data collection using a questionnaire with a five-level Likert scale. Methods of data analysis with multiple regression analysis with data processing techniques using SPPS version 25.0. This study shows that work motivation has a positive but insignificant effect on employee performance, compensation has a positive and significant impact on employee performance, and collectively, employee performance is influenced positively and significantly by work motivation and compensation. The correlation coefficient has a very strong relationship with the $R$ value of 0.876 , while the coefficient of determination has an $R$ Square value of 0.767 so that the contribution of work motivation and compensation to employee performance is $76.7 \%$, while the rest is by other factors such as competence and work environment. The conclusion is that employee performance can increase when work motivation and compensation also increase.
\end{abstract}

Key words: work motivation, compensation, morale, competence, work environment, employee performance

\section{PENDAHULUAN}

Karyawan menjadi bagian penting dalam suatu perusahaan. Karyawan memberikan kontribusi yang menjadikan operasional perusahaan dapat berjalan sesuai yang sudah direncanakan sebelumnya. Terkait dengan hasil yang sudah dilaksanakan sesuai dengan rencana kerja perusahaan tentu kinerja perusahaan tidak dapat dipisahkan dengan kinerja yang sudah dilakukan oleh karyawan itu sendiri. Perusahaan memiliki kepentingan dalam peningkatan kinerja seluruh karyawannya (Budihardjo, 2015).

Salah satu faktor yang terkait dengan kinerja karyawan yaitu faktor motivasi. Motivasi kerja menjadi pendorong yang membuat karyawan menjadi sungguhsungguh dalam melaksanakan pekerjaannya. Motivasi pada karyawan pada dasarnya ada diri pribadi tetapi tetap menjadi penting agar selalu diperhatikan oleh pihak manajemen sehingga energi positif karyawan dalam bekerja terus terjaga. Griffin dalam (Busro, 2018) berpendapat bahwa motivasi menjadi salah satu pertimbangan penting karena dapat berpengaruh terhadap kinerja pada individu selain faktor lingkungan dan kemampuan.

Kompensasi menjadi bagian lain yang juga penting dan perlu diperhatikan perusahaan terkait dengan kinerja karyawan. Kompensasi yang diberikan menjadi perhatian khusus perusahaan sehingga kesejahteraan dan hak lain yang diterima karyawan baik finansial dan yang bukan bersifat finansial tetap diterima sesuai kelayakan dan terjamin. Pemberian kompensasi menjadi tantangan bagaimana perusahaan tetap bijak dalam memberikan yang terbaik bagi karyawannya sesuai dengan keadaan dan kemampuan yang ada. Salah satu pernyataan Schuler dan Jackson dalam (Herlintati, 2020) bahwa kompensasi memberikan motivasi dalam mencapai kinerja.

Motivasi kerja dan kompensasi menjadi penting sehingga kinerja karyawan diharapkan tetap baik. Motivasi yang naik turun pada setiap individu menjadi 
gambaran umum yang dihadapi setiap perusahaan seperti karyawan yang terkadang tidak tepat waktu hadir dalam bekerja dan kurang bersemangat dalam kerjanya. Selanjutnya terkadang kurangnya perhatian dari pimpinan untuk memberi motivasi juga menjadi masalah lain yang muncul terkait motivasi ini. Terkait dengan kompensasi permasalahan yang ada biasanya dihubungkan dengan kebijakan kompensasi yang masih jauh dari harapan dan tidak sesuai bagi karyawan. Permasalahan seperti pemberian tunjangan selain gaji pokok yang masih jauh dari harapan, jenjang karir yang tidak pasti, dan kurangnya hiburan bagi karyawan menjadi contoh persoalan bagi karyawan dari sisi finansial maupun bukan finansial tetapi juga menjadi tantangan bagi pihak manajemen untuk mengambil keputusan yang lebih bijak lagi dalam pemenuhan kebutuhan dan keinginan karyawannya.

PT Matahari Department Store merupakan salah satu perusahaan ritel yang bermitra dengan banyak pemasok terpercaya di Indonesia yang menyediakan kebutuhan masyarakat khususnya rumah tangga. Dalam operasional usahanya PT Matahari Department Store tentu memerlukan kinerja yang efektif dari karyawannya dalam memberikan pelayanan perusahaannya. Terkait dengan perluya kinerja karyawan tersebut tentu menjadi prioritas perusahaan untuk selalu memberi perhatian. Dalam hal ini tentunya perhatian terhadap motivasi kerja dan kompensasi juga perlu menjadi bagian penting sehingga nantinya muncul kinerja karyawan yang tetap sesuai harapan dan standar yang sudah ditentukan perusahaan.

Penelitian oleh Nabawi et al., 2018 di PT Arwana Anugerah Keramik menyatakan bahwa secara parsial kinerja karyawan dipengaruhi dengan positif dan signifikan oleh motivasi dan kompensasi, dan secara simultan variabel bebas tersebut juga mempunyai pengaruh terhadap kinerja karyawan. Setiadi et al., 2016 dalam penelitiannya di PT Semen Indonesia (Persero) dengan jumlah responden 75 orang karyawan juga menemukan bahwa kinerja karyawan secara parsial dan simultan dipengaruhi oleh motivasi dan kompensasi. Penelitian oleh Ekundayo,
2018 dengan hipotesis yang diuji menggunakan alat statistik Chi-square memberikan hasil penelitian faktor utama yang mempengaruhi kinerja karyawan adalah motivasi dan penelitiannya menunjukkan hubungan langsung yang kuat dan positif antara motivasi karyawan dan kinerja. Gachengo \& Wekesa, 2017 dalam penelitiannya memberikan informasi sebanyak 95 responden karyawan kantor pusat Nairobi yang menjadi sampel ditemukan bahwa secara statistik kinerja karyawan di National Bank of Kenya dipengaruhi dengan signifikan oleh motivasi. Hameed et al., 2014 dalam penelitiannya yang dilakukan pada 200 karyawan di 45 Bank di Punjab Selatan yang diambil secara acak menemukan kompensasi dengan uji korelasi memiliki dampak yang positif terhadap kinerja karyawan meskipun dengan uji regresi tidak signifikan. (Rahmawathi \& Supartha, 2018) juga meneliti tentang kompensasi dan kinerja karyawan yang menunjukkan bahwa kinerja karyawan di Universitas Mahasaraswati dipengaruhi oleh kompensasi.

Motivasi menurut Robbin dan Judge dalam Busro (2018) menyatakan bahwa motivasi sebagai proses yang dapat memberikan penjelasan tentang keadaan tingkatan, ketekunan, dan arah untuk mencapai maksud atau tujuan pada seseorang. Mangkunegara dalam Busro (2018) dikatakan bahwa indikator motivasi tersebut dapat diperoleh dari berbagai lima kebutuhan yaitu berupa fisiologis, kebersamaan, harga diri, rasa aman, dan aktualisasi diri. Garry Dessler dalam Herlintati (2020) memberikan pendapat bahwa kompensasi sebagai imbalan yang diberikan kepada pegawai atas tugas atau prestasi yang dilakukan dalam pekerjaannya. Pemberian kompensasi untuk karyawan dapat berbentuk finansial seperti gaji dan tunjangan dan non financial berupa penghargaan atau promosi dalam jabatan Martoyo dalam Herlintati (2020).

Pendapat Mathis dan Jackson dalam Busro (2018) bahwa kinerja adalah hasil dari yang dilakukan dalam pekerjaan dan yang tidak dilakukan oleh pegawai. Menurut (Kasmir, 2016) ada beberapa dimensi dalam kinerja karyawan yaitu dimensi kejujuran, dimensi kemampuan, dimensi kepatuhan, 
dimensi kepemimpinan, dimensi kejujuran, dimensi absensi, dimensi tanggung jawab, dimensi loyalitas, dan yang terakhir dimensi kerjasama

\section{METODOLOGI}

Jenis penelitian kuantitatif digunakan dalam penelitian ini untuk mengetahui pengaruh variabel satu dengan variabel lainnya. Metode pengumpulan data pada penelitian ini menggunakan kuesioner dengan lima skala likert. Arikunto dalam Nugroho (2018) menyatakan kuesioner sebagai informasi yang diperoleh dari responden berupa data pribadi atau materi lain terkait penelitian yang perolehananya dengan memberikan sekumpulan pertanyaan. Populasi sekaligus sampel pada penelitian adalah seluruh karyawan yang bertugas sebagai kasir pada PT Matahari department Store Cabang Cibubur yang lokasinya di daerah Cibubur yang masuk dalam wilayah Jakarta Timur. Jumlah kasir yang bekerja pada saat penelitian sejumlah 32 orang dan semuanya dijadikan responden. Arikunto dalam penelitian (Karomah, 2019) menyatakan jika jumlah subjek dibawah 100, lebih baik dijadikan seluruhnya menjadi subjek.

Variabel yang digunakan dalam penelitian ini yaitu dua variabel bebas yang terdiri dari variabel motivasi kerja $\left(X_{1}\right)$ dan variabel kompensasi $\left(\mathrm{X}_{2}\right)$. Untuk variabel tergantung hanya ada satu yaitu variabel kinerja karyawan $(Y)$. Setelah dilakukan uji validitas beserta uji reliabilitas dalam penelitian ini kemudian dilakukan analisis data berupa analisis regresi dengan uji t, uji $F$, korelasi koefisien, dan koefisien determinasi. Teknik untuk mengolah data digunakan program komputer SPPS dalam versi 25.0.

\section{HASIL PEMBAHASAN Uji Validitas}

Setelah dilakukan olah data dengan SPPS versi 25.0 dapat dihasilkan uji validitas untuk variabel motivasi kerja (X1), variabel kompensasi (X2), dan variabel kinerja karyawan (Y). Hasil menunjukkan bahwa pertanyaan pada ketiga variabel yang jumlahnya masing-masing sepuluh item semuanya dinyatakan valid atau sahih. Nilai $r$ hitung product moment pada keluaran SPSS semuanya pada nilai signifikansi 0,05 dan hasil perhitungan semua item bernilai lebih dari 0,3. Menurut Sugiyono dalam (Rukajat, 2018) dinyatakan instrumen disebut valid jika pertanyaan yang diberikan hasilnya korelasi positif dan angkanya $>0,3$.

\section{Uji Reliabiltas}

Azwar dalam Djasuli (2015) reliabilitas menunjukkan instrument yang terkait mempunyai kepercayaan. Dengan menggunakan Cronbach's Alpha pada SPSS, uji reliabilitas pada penelitian ini hasilnya dapat ditunjukkan pada Tabel 1 . Nilai Cronbach's Alpha untuk ketiga variabel pada tabel 1 angkanya diatas 0,60 sehingga semua pertanyaan variabel motivasi kerja $\left(\mathrm{X}_{1}\right)$, variabel kompensasi $\left(\mathrm{X}_{2}\right)$, dan variabel kinerja karyawan $(Y)$ semuanya dinyatakan reliabel atau memiliki keandalan.

Tabel 1. Hasil Uji Reliabilitas

\begin{tabular}{|c|c|}
\hline Variabel & Cronbach's Alpha \\
\hline Motivasi kerja & 0,777 \\
\hline Kompensasi & 0,877 \\
\hline Kinerja Karyawan & 0,863 \\
\hline
\end{tabular}

\section{Uji Normalitas}

Berdasarkan uji Probability Plot dapat diketahui bahwa data memiliki distribusi normal dengan titik tiitik yang ada di sekitar garis dan searah dengan garis tersebut (Gambar 1).

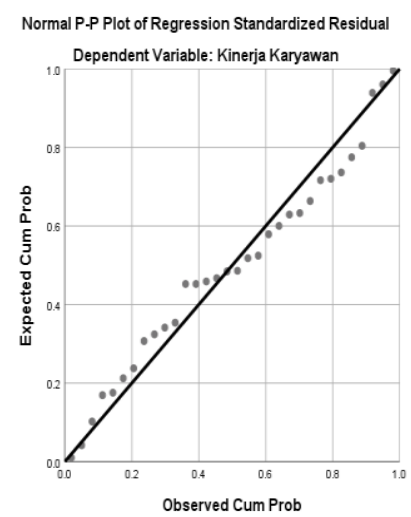

Gambar 1. Normal Probability Plot

\section{Uji Linearitas}

Berdasarkan Tabel 2 hasil perhitungan menunjukkan ada linearitas antara motivasi kerja dengan kinerja karyawan. Diketahui nilai Sig baris Deviation from Linearity = 0,214 lebih besar daripada 0,05. 
Tabel 2. Hasil Uji Linearitas Motivasi Kerja dengan Kinerja Karyawan

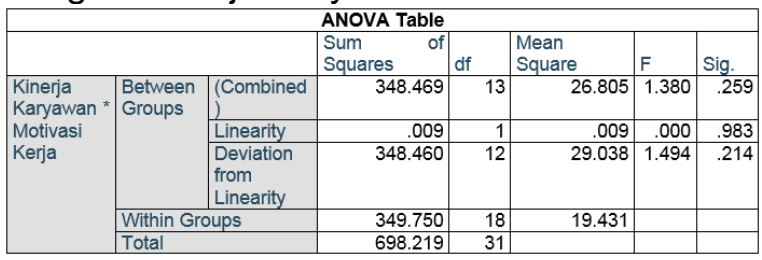

Tabel 3. Uji Linearitas Kompensasi dengan Kinerja Karyawan

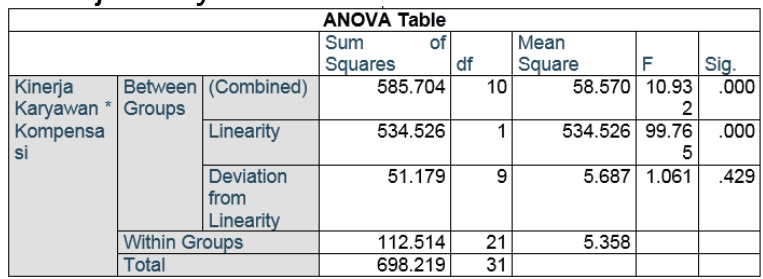

Berdasarkan Tabel 3 ditunjukkan juga linearitas antara kompensasi dengan kinerja karyawan. Diketahui dalam tabel tersebut nilai Sig baris Deviation from Linearity = 0,429 lebih besar daripada 0,05.

\section{Uji Multikolinearitas}

Tabel 4 pada penelitian menunjukkan hasil perhitungan multikolinearitas. Perhitungan Tabel 4 dapat diketahui antara variabel motivasi kerja dengan variabel kompensasi tidak ada multikolineariatas. Angka ditunjukkan dengan kedua variabel tolerance nilainya di bawah angka 1 dan nilai VIFnya mendekati angka 1.

Tabel 4. Hasil Uji Multikolinearitas

\begin{tabular}{|c|c|c|}
\hline $\begin{array}{c}\text { Variabel } \\
\text { Independent }\end{array}$ & Tolerance & VIF \\
\hline Motivasi Kerja & 0,998 & 1,002 \\
\hline Kinerja karyawan & 0,998 & 1,002 \\
\hline
\end{tabular}

\section{Uji Heteroskedastisitas}

Hasil uji heteroskedastisitas dapat dilihat pada Gambar 2.

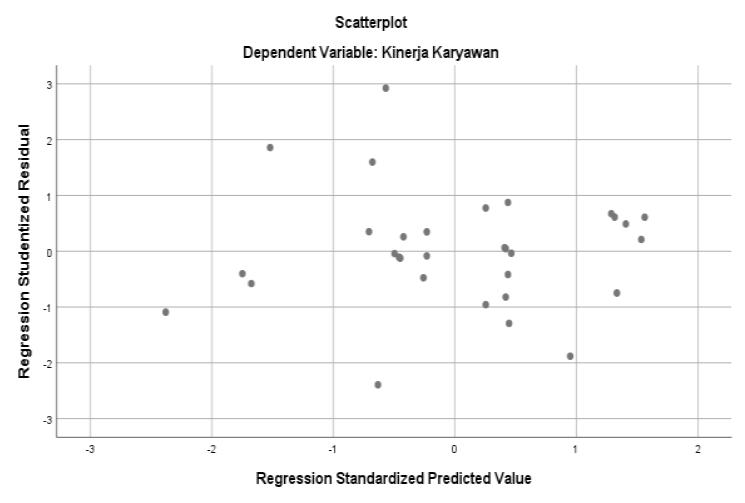

Gambar 2. Hasil Uji Heteroskrdastisitas
Pada gambar tersebut dapat diketahui bahwa pada penelitian ini tidak ada heteroskedastisitas. Untuk diketahui bahwa titik-titik yang ada terletak acak pada sumbu $Y$ dengan di atas angka 1 dan juga di bawah angka 1.

\section{Koefisien Korelasi dan Determinasi}

Berdasarkan Tabel 5 dapat diketahui bahwa nilai $R$ atau koefisien korelasi 0,876 berarti variabel motivasi kerja dan variabel kompensasi dengan kinerja karyawan bagian kasir mempunyai hubungan yang sangat kuat. Angka 0,767 mempunyai arti bahwa koefisien determinasi pada penelitian ini menunjukkan bahwa kontribusi motivasi kerja dan kompensasi terhadap kinerja karyawan bagian kasir sebesar 76,7 $\%$ sisanya 23,3 dipengaruhi variabel yang tidak diikutkan pada penelitian misalnya kompetensi dan faktor lingkungan kerja.

Tabel 5. Hasil Model Summary

\begin{tabular}{|l|l|r|ll|ll|}
\hline \multicolumn{7}{|c|}{ Model Summary } \\
\hline Model & $R$ & R Square & $\begin{array}{l}\text { Adjusted } \\
\text { Square }\end{array}$ & $\begin{array}{l}\text { Std. Error of the } \\
\text { Estimate }\end{array}$ \\
\hline 1 & $.876^{\mathrm{a}}$ & .767 & & .751 & & 2.370 \\
\hline a. Predictors: (Constant), Kompensasi, Motivasi Kerja & & \\
\hline b. Dependent Variable: Kinerja Karyawan & & \\
\hline
\end{tabular}

\section{Uji Regresi}

Berdasarkan perhitungan yang terlihat pada Tabel 6 didapatkan persamaan regresi $Y=2,320+0,038 X_{1}+0,912 X_{2}$ yang artinya konstanta 2,320 artinya jika motivasi kerja dan kompensasi tidak ada atau nol maka kinerja karyawan nilainya 2,320 satuan. Jika motivasi kerja ada kenaikan sebesar satu satuan maka kinerja karyawan naik dengan besaran 0,038 dengan asumsi kompensasi angkanya tetap. Selanjutnya apabila kompensasi naik sebesar satu satuan maka kinerja karyawan naik dengan besaran 0,912 dengan asumsi motivasi kerja angkanya tetap. Dari persamaan tersebut diketahui terdapat hubungan positif atau artinya searah yang berarti variabel motivasi kerja dan kompensasi meningkat maka meningkat pula kinerja karyawan. Nilai $t$ hitung motivasi kerja 0,336 dengan sig. 0,717 dimana nilai lebih besar dari 0,05 maka kinerja karyawan tidak dipengaruhi secara signifikan oleh motivasi kerja, jadi hipotesis pertama tidak diterima.

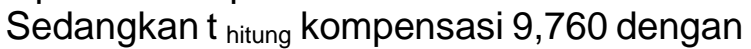
sig 0,000 dimana nilai lebih kecil dari nilai 
0,05 maka secara signifikan kinerja karyawan dipengaruhi oleh kompensasi, jadi hipotesis kedua pada penelitian ini diterima.

Tabel 6. Hasil Regresi Linear Ganda

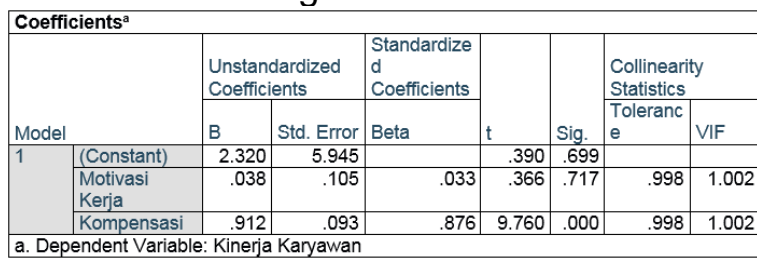

Tabel 7. Uji Signifikansi Persamaan Regresi Linear Ganda (Uji F)

\begin{tabular}{|c|c|c|c|c|c|c|}
\hline \multicolumn{7}{|c|}{ ANOVA $^{a}$} \\
\hline \multicolumn{2}{|l|}{ Model } & $\begin{array}{|ll|}\text { Sum } & \text { of } \\
\text { Squares } & \end{array}$ & df & $\begin{array}{l}\text { Mean } \\
\text { Square }\end{array}$ & $F$ & \\
\hline 1 & Regression & 535.278 & 2 & 267.639 & 47.634 & $.000^{\mathrm{b}}$ \\
\hline & Residual & 162.941 & 29 & 5.619 & & \\
\hline & Total & 698.219 & 31 & & & \\
\hline
\end{tabular}

Berdasarkan Tabel 7 diketahui secara bersama-sama variabel motivasi kerja dan kompensasi mempunyai pengaruh yang signifikan terhadap kinerja karyawan. Hal ini dapat dilihat pada angka $F$ hitung 47,643 dengan sig 0,000 dimana lebih kecil dari 0,05 . Jadi dalam penelitian ini hipotesis ketiga dapat diterima.

Terdapat pengaruh yang positif dan tidak signifikan antara motivasi kerja dengan kinerja karyawan bagian kasir PT Matahari department Store Cabang Cibubur. Hasil positif menunjukkan bahwa semakin bertambah motivasi yang dimiliki semakin bertambah kinerja karyawan meskipun motivasi kerja ini tidak berperan signifikan pada kinerja karyawan bagian kasir. Dalam hal ini, ada yang kurang dalam menjaga motivasi karyawan bagian kasir sehingga perlu perbaikan, perhatian, dan dorongan dalam pemenuhan kebutuhan fisik atau non fisik yang dibutuhkan dan diinginkan karyawan yang tentu disesuaikan dengan kinerja dan kondisi gambaran karyawan dilapangan. Penelitian ini sependapat dengan penelitian (Ekundayo, 2018) terkait hubungan positif antara motivasi dengan kinerja karyawan tetapi tidak sependapat dengan (Gachengo \& Wekesa, 2017) yang hasilnya terdapat pengaruh yang signifikan antara motivasi dengan kinerja karyawan.

Terdapat pengaruh yang positif dan signifikan antara kompensasi dengan kinerja karyawan bagian kasir PT Matahari department Store Cabang Cibubur. Hasil positif menunjukkan bahwa semakin bertambah kompensasi yang dimiliki semakin bertambah kinerja karyawan atau sebaliknya jika kompensasi turun makan kinerja karyawan juga mengalami penurunan. Karyawan bagian kasir memerlukan penghargaan dan kejelasan karir yang pasti dalam pekerjaaanya sehingga selanjutnya kinerja karyawan menjadi lebih baik lagi. Penelitian ini sesuai dengan pendapat penelitian (Rahmawathi \& Supartha, 2018) tetapi tidak sepenuhnya sependapat dengan penelitian (Hameed et al., 2014) yang hasilnya ada hubungan positif tetapi secara analisis regresi hasinya ternyata tidak siginifikan. Terdapat pengaruh yang positif dan signifikan antara motivasi kerja dan kompensasi secara bersama-sama dengan kinerja karyawan bagian kasir PT Matahari department Store Cabang Cibubur. Hasil positif menunjukkan bahwa semakin bertambah motivasi kerja dan kompensasi yang dimiliki semakin bertambah kinerja karyawan. Karyawan bagian kasir menjadikan motivasi kerja dan kompensasi bersama-sama menjadi pendorong dan penyemangat dalam melaksanakan pekerjaan. Penelitian ini sesuai dengan pendapat penelitian Nabawi et al., (2018) dan Setiadi et al., (2016).

\section{KESIMPULAN}

Hasil penelitian menunjukkan bahwa secara parsial kinerja karyawan dipengaruhi secara positif tetapi tidak signifikan oleh motivasi kerja. Hasil penelitian menunjukkan bahwa secara parsial kinerja karyawan dipengaruhi secara positif dan signifikan oleh kompensasi. Hasil penelitian menunjukkan dari sisi simultan bahwa kinerja karyawan bagian kasir PT Matahari department Store Cabang Cibubur dipengaruhi secara positif dan secara signifikan oleh motivasi kerja dan kompensasi. Hasil yang positif memberikan arti semakin meningkat motivasi kerja dan kompensasi yang diberikan dapat meningkatkan kinerja karyawan. Hasil simultan juga didukung dengan besarnya sumbangan motivasi kerja dan kompensasi terhadap kinerja karyawan 76,7 persen nilai koefisien determinasi. 
Kompensasi mempunyai pengaruh besar terhadap kinerja sehingga pengelolaan kompensasi diharapkan diperhatikan lagi dengan mempertahankan kompensasi yang sudah ada dan bisa meningkatkan tunjangan selain gaji pokok yang ada seperti ditambahnya insentif yang tentunya bagi karyawan yang berprestasi atau memiliki kinerja baik dan melebihi standar yang sudah ditentukan. Kompensasi bukan yang yang financial saja tetapi yang non financial juga perlu diperhatikan seperti kejelasan karir atau promosi dalam pekerjaan yang tentu disesuaikan dengan melihat kondisi perusahaan. Motivasi kerja tetap selalu diperhatikan sehingga dorongan kerja yang positif karyawan terus bertambah. Hal ini dapat dilakukan dengan lebih peduli dari pihak pimpinan untuk terus melakukan komunikasi dan menyemangati karyawan dalam melakukan pekerjaan dengan selalu memberikan perhatian terhadap karyawan seperti memberikan pujian, bonus kerja, atau penghargaan lain atas hasil kerja karyawan yang telah dilakukan.

\section{DAFTAR PUSTAKA}

Budihardjo, M. (2015). Panduan Praktis Penilaian Kinerja Karyawan. Jakarta: Raih Asa Sukses (Penebar Swadaya Group).

Busro, M. (2018). Teori-Teori Manajemen Sumber Daya Manusia. Jakarta: Prenadamedia Group (Group Kencana).

Djasuli, M. (2015). Studi Eksplanatoris Kompetensi Dosen Ekonomi Terhadap Kinerja Dosen Fakultas Ekonomi Di Universitas Trunojoyo Madura. Pamator, 8(2), 147-154.

Ekundayo, O. A. (2018). The Impact of Motivation on Employee Performance in Selected Insurance Companies in Nigeria Oluwayomi Ayoade Ekundayo, Joseph Ayo Babalola University, Nigeria. International Journal of African Development, 5(1), 31-42. Retrieved from https://scholarworks.wmich.edu/ijad/vol5/i ss $1 / 5 /$

Gachengo, V., \& Wekesa, S. (2017). Influence of motivation on employee performance: a case of national bank of Kenya. International Journal of Business
Management and Social Research, 3(2), 179-185.

https://doi.org/10.18801/ijbmsr.030217.20

Hameed, A., Ramzan, M., Zubair, H. M. K., Ali, G., \& Arslan, M. (2014). Impact of Compensation on Employee Performance (Empirical Evidence from Banking Sector of Pakistan). International Journal of Business and Social Science, 5(2), 302309.

Herlintati. (2020). Budaya Kerja, Kompensasi, dan Kinerja Tenaga Medis. Yogyakarta: Penerbit Ikatan Guru Indonesia (IGI) DIY.

Karomah, R. (2019). Analisis Pengaruh Konflik Peran Ganda dan Stres Kerja terhadap Kinerja Karyawan Wanita Menikah (Studi pada PT. Sukorintex Batang). AKSES: Jurnal Ekonomi Dan Bisnis, 14(2), 71-82.

Kasmir. (2016). Manajemen Sumber Daya Manusia (Teori dan Praktik). Jakarta: Rajagrafindo Persada.

Nabawi, D., Zunaidah, \& Kosasih, Z. M. (2018). The Influence Of Compensation And Motivation On Employee Performance In PT Arwana Anugerah Keramik Tbk. Jembatan - Jurnal Ilmiah Manajemen Bisnis dan Terapan, XV(1), 18.

Nugroho, E. (2018). Prinsip-Prinsip Menyusun Kuesioner. Malang: UB Press.

Rahmawathi, N. P. D., \& Supartha, W. G. (2018). The Effect of Compensation on Employee Performance Mediated by Organizational Commitments. The International Journal Of Humanities \& Social Studies, 6(9), 286-295.

Rukajat, A. (2018). Pendekatan Penelitian Kuantitatif: Quantitative Research Approach (1st ed.). Yogyakarta: Penerbit Deepublish.

Setiadi, R. U., Setiadi, P. B., \& Indroyono. (2016). The Effect of Compensation and Work Motivation on Employee Performance at Semen Indonesia Limited Company. International Journal of Academic Research and Reflection, 4(3), 64-85. 